\title{
ANALISA FAKTOR-FAKTOR YANG BERHUBUNGAN DENGAN PEMBERIAN MATERI PENDIDIKAN KESEHATAN REPRODUKSI PADA SISWA SEKOLAH DASAR DI KECAMATAN SEMARANG TIMUR KOTA SEMARANG
}

\author{
ANALYSIS OF FACTORS RELATED TO GIVING REPRODUCTIVE HEALTH EDUCATION \\ MATERIALS IN BASIC SCHOOL STUDENTS IN DISTRICT SEMARANG TIMUR SEMARANG CITY
}

\author{
$\underline{\text { Widyah Setiyowati }^{1}, \text { Sri Mularsih }}{ }^{2}$, Frida Cahyaningrum ${ }^{3}$ \\ 1,2,3 Akademi Kebidanan Abdi Husada Semarang \\ Email : widyahsetiyowati@gmail.com
}

\begin{abstract}
ABSTRAK
Pendidikan kesehatan reproduksi merupakan bagian dari pendidikan kesehatan yang hakekatnya adalah suatu bentuk intervensi untuk menciptakan perilaku yang kondusif untuk kesehatan. Hal ini akan berjalan dengan baik jika dilakukan dalam lingkungan yang terorganisir seperti lingkungan sekolah. Sekolah merupakan tempat yang ideal untuk memberikan pendidikan kesehatan khususnya kesehatan reproduksi remaja. Pendidikan kesehatan reproduksi berbasis sekolah adalah salah satu cara yang paling penting dan luas untuk membantu remaja mengenali dan menghindari resiko berkaitan dengan kesehatan reproduksi dan meningkatkan pengetahuan tentang kesehatan reproduksi. Penelitian ini bertujuan untuk mengetahui hubungan sikap, persepsi dan dukungan kepala sekolah dengan perilaku guru dalam pemberian materi pendidikan kesehatan reproduksi pada siswa sekolah dasar di kecamatan Semarang Timur Kota Semarang. Penelitian ini termasuk dalam penelitian explanatory research yaitu menjelaskan hubungan antara variabel bebas dan variabel terikat melalui pengujian hipotesa yang telah dirumuskan. Metode yang digunakan dalam penelitian ini adalah metode survey dengan menggunakan pendekatan cross sectional/ belah lintang, dimana variabel bebas dan variabel terikat diteliti dalam waktu secara serentak. Jumlah sampel 34 responden, analisa data menggunakan chi square. Hasil penelitian ini menunjukkan ada hubungan antara persepsi, sikap dan dukungan kepala sekolah dengan perilaku pemberian materi pendidikan kesehatan reproduksi pada siswa sekolah dasar di Kecamatan Semarang Timur Kota Semarang berdasarkan atas hasil Sig $\leq 0,05$ sehingga Ho ditolak. Saran dalam penelitian ini ditujukan kepada guru, institusi pendidikan, tenaga kesehatan dan masyarakat untuk mendukung pemberian pendidikan kesehatan reproduksi sesuai dengan usia anak.
\end{abstract}

Kata Kunci : Faktor-faktor, Pendidikan kesehatan reproduksi

\begin{abstract}
Reproductive health education is part of health education which is essentially a form of intervention to create behaviors that are conducive to health. This will work well if done in an organized environment such as the school environment. Schools are ideal places to provide health education, especially adolescent reproductive health. School-based reproductive health education is one of the most important and broad ways to help adolescents recognize and avoid risks related to reproductive health and increase knowledge about reproductive health. This study aims to determine the relationship of attitudes, perceptions and support of principals to the behavior of teachers in the provision of reproductive health education materials for elementary school students in the East Semarang sub-district of Semarang City. This research was included in an explanatory research study that explained the relationship between independent variables and dependent variables through hypothesis testing that had been formulated. The method used in this study is a survey method using cross sectional approach, where the independent variables and dependent variables are examined simultaneously. The number of samples is 34 respondents, data analysis uses chi square. The results of this study indicate there is a relationship between perceptions, attitudes and support of school principals with the behavior of giving reproductive health education materials to elementary school students in East Semarang Subdistrict, Semarang City based on the results of Sig $\leq 0,05$ so Ho is rejected. Suggestions in this study are for teachers, educational institutions, health workers and the community to support the provision of reproductive health education in accordance with the age of children.
\end{abstract}

Keywords: Factors, Reproductive health education 


\section{PENDAHULUAN}

Memasuki masa remaja awal yang ditandai dengan terjadinya kematangan seksual, maka remaja dihadapkan pada keadaan yang memerlukan penyesuaian untuk dapat menerima perubahanperubahan yang terjadi. Kematangan seksual dan terjadinya perubahan bentuk tubuh sangat berpengaruh pada kehidupan kejiwaan remaja. Kurangnya pemahaman tentang perilaku seksual pada masa remaja sangat merugikan bagi remaja sendiri termasuk keluarganya. Kurangnya pemahaman ini disebabkan oleh berbagai faktor antara lain adat istiadat, budaya, agama dan kurangnya informasi dari sumber yang benar. ${ }^{3)}$

Menurut Notoatmojo Pendidikan kesehatan reproduksi merupakan bagian dari pendidikan kesehatan yang hakekatnya adalah suatu bentuk intervensi untuk menciptakan perilaku yang kondusif untuk kesehatan. Hal ini akan berjalan dengan baik jika dilakukan dalam lingkungan yang terorganisir seperti lingkungan sekolah. Sekolah merupakan tempat belajar sebagian besar remaja merupakan tempat yang ideal untuk memberikan pendidikan kesehatan khususnya kesehatan reproduksi remaja. ${ }^{1)}$ Sejak awal tahun 1980-an, lingkungan sekolah telah menjadi salah satu lokasi kunci program pendidikan kesehatan. Menurut Badan Kesehatan Dunia (World Health Organisation, WHO) pendidikan kesehatan reproduksi berbasis sekolah adalah salah satu cara yang paling penting dan luas untuk membantu remaja mengenali dan menghindari resiko berkaitan dengan kesehatan reproduksi dan meningkatkan pengetahuan tentang kesehatan reproduksi. ${ }^{12)}$ Sejalan dengan hasil Survey Kesehatan Reproduksi Remaja tahun 2012 bahwa remaja perempuan maupun laki-laki lebih mengharapkan informasi kesehatan reproduksi diberikan oleh guru sejumlah $60,8 \%$. Akan tetapi hasil riset pada tahun 2010 di Jakarta tentang sikap guru SD tentang pendidikan kesehatan reproduksi dimana hanya $41,3 \%$ guru yang mendukung diberikannya pendidikan kesehatan reproduksi pada anak SD. ${ }^{21)}$ Hal tersebut juga sejalan dengan riset yang dilakukan di Kota Semarang bahwa 65\% guru belum pernah mengikuti pelatihan tentang pendidikan kesehatan kesehatan reproduksi. ${ }^{26)}$ Para guru masih merasa kurang nyaman menyampaikan pendidikan kesehatan reproduksi. Selain itu belum adanya kurikulum yang berlaku secara nasional menjadi hal kurangnya dukungan dinas dalam pelaksanaan pendidikan kesehatan reproduksi di sekolah. ${ }^{5)}$

Standar kurikulum SD belum ada kurikulum yang mengatur pelaksaan pendidikan kesehatan reproduksi, materi yang berkaitan dengan kesehatan reproduksi terintegrasi dengan mata pelajaran IPA kelas VI semester 1 dan diberikan oleh guru kelas masing-masing, selain itu belum ada pelatihan tentang pendidikan kesehatan reproduksi pada guru SD baik oleh dinas kesehatan maupun dinas pendidikan atau kerjasama keduanya. ${ }^{18)}$ Sehingga dengan belum adanya aturan di kurikulum tentang pendidikan kesehatan reproduksi membuat sekolah sulit memberikan pendidikan kesehatan reproduksi diluar pelajaran yang terintegrasi, namun ada beberapa sekolah yang memiliki strategi dalam memberikan pendidikan kesehatan kesehatan reproduksi dengan memperhatikan kemampuan yang dimiliki sekolah. Hasil riset di kota semarang tahun 2015 menunjukkan bahwa $73 \%$ SD membutuhkan pendidikan kesehatan reproduksi bagi para siswanya yang didukunng pula dengan perbaikan materi, kualitas guru, sarana prasarana dan juga kebijakan tentang kurikulum yang mendukung pemberian meteri tersebut. ${ }^{26)}$

Meninjau dari hal tersebut diatas pendidikan kesehatan reproduksi pada tingkatan Sekolah Dasar sangat penting untuk diberikan jika sesuai dengan batasannya dan dengan adanya kurikulum maka akan meningkatkan pendidikan kesehatan reproduksi sesuai standar yang telah ditetapkan karena pendidikan kesehatan reproduksi dapat memberikan pemahaman remaja akan kondisi tubuhnya, pemahaman akan lawan jenisnya, dan 
pemahaman untuk menghindarkan dari kekerasan seksual.

Berdasarkan uraian diatas maka penulis tertarik untuk melakukan penelitian tentang "Analisa Faktor-faktor yang Berhubungan dengan Pemberian Materi Pendidikan kesehatan reproduksi pada Siswa Sekolah Dasar di Kecamatan Semarang Timur Kota Semarang"

\section{METODE PENELITIAN}

Penelitian ini termasuk dalam penelitian explanatory research yaitu menjelaskan hubungan antara variabel bebas dan variabel terikat melalui pengujian hipotesa yang telah dirumuskan. Metode yang digunakan dalam penelitian ini adalah metode survey dengan menggunakan pendekatan cross sectional/ belah lintang, dimana variabel bebas dan variabel terikat diteliti dalam waktu secara serentak.

Tehnik pengambilan sampel adalah sampel jenuh yaitu menggunakan semua populasi sebagai sampel sehingga jumlah sampel dalam penelitian ini adalah 34 orang. Instrumen penelitian ini menggunakan kuesioner yang berisi tentang pertanyaan mengenai sikap, persepsi, dukungan terhadap pendidikan kesehatan reproduksi dan perilaku dalam memberikan materi pendidikan kesehatan reproduksi

Analisis data dilakukan dengan analisis univariat dan bivariate. Analisis univariat dilakukan dengan tujuan untuk menggambarkan setiap variabel independent (sikap, persepsi, dukungan) dan variabel dependen (perilaku) yang diteliti secara terpisah dengan cara membuat tabel frekuensi atau grafik dari masingmasing variabel. Analisis bivariate dilakukan dengan cara tabulasi silang untuk melihat pola hubungan antara variabel bebas dan variabel terikat yang diteliti. Analisis data menggunakan tehnik analisis statistic chi square.
HASIL DAN PEMBAHASAN

a. Analisa Univariat

1) Persepsi

Tabel 1 Persepsi Responden

\begin{tabular}{lll}
\hline Kategori & Frekuensi & \% \\
\hline Kuat & 26 & 76.5 \\
Lemah & 8 & 23.5 \\
\hline Total & 34 & 100 \\
\hline
\end{tabular}

Dari tabel 1 menunjukkan bahwa responden dengan persepsi kuat lebih banyak $26 \quad(76,5 \%)$ dibandingkan dengan responden dengan persepsi lemah. Persepsi adalah tanggapan langsung dari suatu proses seseorang mengetahui beberapa hal melalui panca inderanya. Menurut Pareek persepsi sebagai proses menerima, menyeleksi, mengorganisasi, mengarahkan, menguju dan memberikan reaksi kepada rangsangan panca indera atau data. Persepsi adalah sumber pengetahuan tentang lingkungan sekitar

2) Sikap

Tabel no .2. Sikap Responden

\begin{tabular}{lll}
\hline Kategori & Frekuensi & \% \\
\hline Positif & 26 & 76.5 \\
Negatif & 8 & 23.5 \\
\hline Total & 34 & 100 \\
\hline
\end{tabular}

Dari tabel 2 menunjukkan bahwa responden dengan sikap positif tentang pendidikan kesehatan reproduksi lebih besar $26(76,5 \%)$ dibandingkan dengan responden dengan sikap negatif. Menurut Notoadmodjo (2007) Sikap adalah keadaan mental dan saraf dari kesiapan, yang diatur melalui pengalaman yang memberikan pengaruh dinamik atau terarah terhadap respon individu pada semua objek dan situasi yang berkaitan dengannya, sikap itu dinamis tidak statis. 
3) Dukungan Kepala Sekolah

Tabel .3.Dukungan Kepala Sekolah

\begin{tabular}{lll}
\hline Kategori & Frekuensi & \% \\
\hline Mendukung & 25 & 73.5 \\
Tidak mendukung & 9 & 26.5 \\
\hline Total & 34 & 100 \\
\hline
\end{tabular}

Dari tabel 3 menunjukkan bahwa responden dengan dukungan kepala sekolah yang mendukung lebih besar $25 \quad(73,5 \%)$ dibandingkan dengan responden yang tidak mendapatkan dukungan kepala sekolah dalam pendidikan kesehatan reproduksi. Diamtteo (1991) mendefinisikan dukungan sebagai dukungan atau bantuan yang berasal dari orang lain seperti teman, keluarga, tetangga, teman kerja dan orang - orang lainnya.

4) Perilaku

Tabel 4. Perilaku guru dalam Pendidikan Kesehatan Reproduksi

\begin{tabular}{lll}
\hline Kategori & Frekuensi & \% \\
\hline Baik & 24 & 70.6 \\
Kurang baik & 10 & 29.4 \\
\hline Total & 34 & 100 \\
\hline
\end{tabular}

Dari tabel 4 menunjukkan bahwa responden yang mempunyai perilaku baik dalam pemberian materi pendidikan kesehatan reproduksi lebih besar $(70,6 \%)$ dibandingkan dengan responden dengan perilaku kurang baik Menurut Solita (1993) perilaku merupakan hasil dari segala macam pengalaman serta interaksi manusia dengan lingkungannya yang terwujud dalam bentuk pengetahuan, sikap dan praktik atau tindakan. Sedangkan menurut skinner merumuskan bahwa perilaku merupakan respon atau reaksi seseorang terhadap stimulus (rangsang dari luar).

\section{b. Analisa Bivariat}

1) Hubungan Persepsi dengan Pemberian materi pendidikan kesehatan reproduksi

Berdasarkan hasil uji statistik hubungan persepsi dengan pemberian materi kesehatan reproduksi didapatkan hasil $\mathrm{p}$ value $0,03 \leq 0,05$ sehingga Ho ditolak dan Ha diterima artinya ada hubungan antara persepsi dengan pemberian materi pendidikan kesehatan reproduksi

Menurut Rahmat (2004) persepsi merupakan pengalaman tentang obyek, peristiwa atau hubungan yang diperoleh dengan menyimpulkan informasi dan menafsirkan pesan. Persepsi dalam arti sempit adalah penglihatan, yaitu bagaimana cara seseorang melihat sesuatu sedangkan dalam arti luas pesepsi adalah pandangan atau pengertian yaitu bagaimana seseorang memandang atau mengartikan sesuatu.

Dalam pemberian pendidikan kesehatan reproduksi/seksualitas masyarakat menganggap bahwa pendidikan kesehatan reproduksiitas merupakan sebuah malapetaka karena adanya persepsi/anggapan yang keliru tentang pendidikan seks. Pendidikan kesehatan reproduksi selalu dianggap identik dengan mengajari remaja untuk berhubungan seks, padahal masalah seksualitas sangat luas dari sejak lahir sampai mati

2) Hubungan Sikap dengan Pemberian materi pendidikan kesehatan reproduksi

Berdasarkan hasil uji statistik hubungan sikap dengan pemberian materi kesehatan reproduksi didapatkan hasil $\mathrm{p}$ value $0,03 \leq 0,05$ sehingga Ho ditolak dan $\mathrm{Ha}$ diterima artinya ada hubungan antara sikap dengan pemberian materi pendidikan kesehatan reproduksi

Sikap adalah kesiapan merespon yang sifatnya positif atau negatif terhadap objek atau situasi secara konsisten. 
Apabila individu memiliki sikap yang positif terhadap suatu objek maka akan siap membantu, memperhatikan, berbuat sesuatu yang menguntungkan objek itu. Sebaliknya, bila individu memiliki sikap yang negatif terhadap suatu objek, maka individu tersebut akan mengecam, mencela, menyerang bahkan membinasakan objek.

Keyakinan diri inilah yang mempengaruhi respon pribadi terhadap objek dan lingkungan sosialnya. Jika individu yakin bahwa melaksanakan pemberian materi pendidikan kesehatan reproduksi pada anak sekolah dasar merupakan kegiatan yang sulit karena pandangan masyarakat yang masih mentabukan pendidikan kesehatan reproduksi pada anak, maka ada kecenderungan dalam diri individu untuk memberikan materi tidak sesuai dengan kompetensi yang harus dicapai. Jika individu meyakini bahwa memberikan materi pendidikan kesehatan reproduksi merupakan tugas dan tanggung jawab yang harus dilaksanakan serta meyakini bahwa memberikan pendidikan kesehatan reproduksi pada anak penting untuk membentuk perilakunya di kemudian hari, maka individu merespon positif terhadap pendidikan kesehatan reproduksi pada anak.

3) Hubungan dukungan kepala sekolah dengan Pemberian materi pendidikan kesehatan reproduksi

Berdasarkan hasil uji statistik hubungan dukungan kepala sekolah dengan pemberian materi kesehatan reproduksi didapatkan hasil $\mathrm{p}$ value $0,009 \leq 0,05$ sehingga Ho ditolak dan Ha diterima artinya ada hubungan antara dukungan kepala sekolah dengan pemberian materi pendidikan kesehatan reproduksi

Gottlieb (dalam Smet, 1994) menyatakan dukungan terdiri dari informasi atau nasehat verbal maupun non verbal, bantuan nyata, atau tindakan yang didapat karena kehadiran orang lain dan mempunyai manfaat emosional atau efek perilaku bagi pihak penerima. Sarafino (2006) menyatakan bahwa dukungan sosial mengacu pada memberikan kenyamanan pada orang lain, merawatnya, atau menghargainya. dukungan kepala sekolah adalah dukungan atau bantuan yang berasal dari orang atau pengambil keputusan di sekolah yang memiliki hubungan sosial akrab dengan individu yang menerima bantuan. Bentuk dukungan ini dapat berupa informasi, tingkah laku tertentu, atapun materi yang dapat menjadikan individu yang menerima bantuan merasa disayangi, diperhatikan, dan bernilai dan menjadikan tujuan pendidikan kesehatan reproduksi tercapai

\section{KESIMPULAN}

Berdasarkan hasil penelitian, maka kesimpulan dalam penelitian ini adalah :

1. Sebagian besar responden $26(76,5 \%)$ memiliki persepsi yang kuat tentang pendidikan kesehatan reproduksi

2. Sebagian besar responden $26(76,5 \%)$ memiliki sikap positif tentang pendidikan kesehatan reproduksi

3. Sebagian besar responden $25(73,5 \%)$ memiliki dukungan kepala sekolah terkait pendidikan kesehatan reproduksi

4. Sebagian besar responden $24(70,6 \%)$ memiliki perilaku yang baik dalam memberikan materi pendidikan kesehatan reproduksi

5. Ada hubungan antara persepsi dengan perilaku guru dalam memberikan materi pendidikan kesehatan reproduksi pada siswa sekolah dasar di Kecamatan Semarang Timur Kota Semarang

6. Ada hubungan antara sikap dengan perilaku guru dalam memberikan materi pendidikan kesehatan reproduksi pada siswa sekolah dasar di Kecamatan Semarang Timur Kota Semarang.

7. Ada hubungan antara dukungan kepala sekolah dengan perilaku dalam 
memberikan materi pendidikan kesehatan reproduksi pada siswa sekolah dasar di Kecamatan Semarang Timur Kota Semarang

\section{DAFTAR PUSTAKA}

Arikunto Suharsini. Prosedur Penelitian suatu Pendekatan Praktek. Rineka Cipta, Jakarta, 2006. Edisi Revisi VI.

Arfan M, Wilopo SA, Wahyuni B. Efektifitas Pendidikan Kesehatan melalui E-File Multimedia Materi KRR dan Tatap muka di Kelas terhadap Peningkatan Pengetahuan Kesehatan Reproduksi Remaja. Berita Kedokteran Masyarakat. 2010

BPS, BKKBN, Kemenkes RI, Measure DHS, ICF Internasional. Survey Kesehatan Reproduksi Remaja 2012. Diakses 3 Oktober 2013

Depkes RI. Laporan Riskedas 2010. Available from : www.litbang.depkes.go.id. Diakses 14 November 2013.

Department of Child Adolecent Health and Development. Promoting Adolescent Sexual and reproductive Health Through Schools in Low Income Countries : an Information Brief. WHO. 2008

Dinas Kesehatan Propinsi Jawa Tengah. Profil Kesehatan Jawa Tengah, 2015.

Direktorat Remaja dan Perlindungan hakhak Kesehatan Reproduksi. Penyiapan Kehidupan Berkeluarga bagi Remaja. BKKBN Pusat, 2011

Dinas Pendidikan Kota Semarang. Profil Pendidikan Kota Semarang. 2015
Dinas Pendidikan Kota Semarang. Panduan Pengembangan Pembelajaran SKKD IPA tingkat SD/MI. 2012.

Ismail Rita. Analisis Faktor yang Berhubungan dengan Sikap Guru di 13 SD di Jakarta terhadap Pendidikan Kesehatan Reproduksi, 2005. www.litbang.depkes.go.id diakses 26 Juni 2013

Kinanti L. Analisis Pelaksanaan Pendidikan Kesehatan Reproduksi di SMA Kota Semarang( tesis 2014).

Kumalasari I, Adhiyantoro I. Kesehatan Reproduksi untuk Mahasiswa Kebidanan dan Keperawatan. Salemba Medika. Jakarta. 2013

Muflihati A. Pelaksanaan Program Pendidikan Kesehatan Reproduksi Remaja berbasis sekolah. Studi Kasus Program Penyuluhan dan Konseling Kesehatan Reproduksi remaja di SMU Muhamadiyah 2 Yogyakarta. UI Jakarta

Nata Lisomon. Pendidikan Seks bagi Remaja, Analisis Pentingnya Pendidikan Seks untuk Anak. Available from : http//Ipminstitut.com. diakses 1 November 2012

Nashirma Monika. Analisis Persepsi Orang tua Terhadap Kebutuhan Pendidikan Kesehatan Reproduksi pada Orangtua siswa kelas VI SD Santo Antonius 2 dan Srondol 2 Semarang (Tesis). 2010.

Pardede N. Masa Remaja. Dalam : Narendra MB, Sularyo TS, Suyitno H, Soetjiningsih, Ranuh ING. Tumbuh Kembang Anak dan Remaja, Buku Ajar I. Sagung Seto, Jakarta, 2008

PILAR PKBI Jawa Tengah. Profil Kasus . 2012. 
Sambas W. Perlindungan Anak. Dalam : Narendra MB, Sularyo TS, Suyitno H, Soetjiningsih, Ranuh ING,. Tumbuh Kembang Anak dan Remaja, Buku Ajar I. Sagung Seto, Jakarta, 2008

Sofyan Henry. Anak SD pun Melakukan Seks Bebas. Available from : www.suaramerdeka.com/2012 April 7. diakses 16 April 2013

Tanuwidjaya S. Kebutuhan Dasar Tumbuh Kembang Anak. Dalam : Narendra MB, Sularyo TS, Suyitno H, Soetjiningsih, Ranuh ING, Tumbuh Kembang Anak dan Remaja, Buku Ajar I. Sagung Seto, Jakarta, 2008.

UNESCO. International Technical Guidance on Sexuality Education. UNESCO. France. 2009

Winanti SR. Problematika Remaja Akibat Kurang Informasi Kesehatan Reproduksi. Universitas Esa Unggul Jakarta. Jurnal Forum Ilmiah Bunga Rampai, Januari 2010, vol 7, no 1.

Yusuf, S. Psikologi Perkembangan Anak dan Remaja. Rosda Karya, Bandung, 2010. 